\title{
Plant Pathogenic Fungi Associated with Coraebus florentinus (Coleoptera: Buprestidae) Attacks in Declining Oak Forests
}

\author{
Claudia Pinna ${ }^{1}$, Benedetto T. Linaldeddu ${ }^{2}{ }^{\circledR}$, Vitale Deiana ${ }^{1}$, Lucia Maddau ${ }^{1}\left({ }^{(}\right.$, \\ Lucio Montecchio $^{2}$ and Andrea Lentini ${ }^{1, * \mathbb{D}}$ \\ 1 Dipartimento di Agraria, Università degli Studi di Sassari, Viale Italia, 39, 07100 Sassari, Italy; \\ clpinna@uniss.it (C.P.); vdeiana@uniss.it (V.D.); lmaddau@uniss.it (L.M.) \\ 2 Dipartimento Territorio e Sistemi Agro-Forestali, Università degli Studi di Padova, Viale dell'Università 16, \\ 35020 Legnaro, Italy; benedetto.linaldeddu@unipd.it (B.T.L.); montecchio@unipd.it (L.M.) \\ * Correspondence: lentini@uniss.it
}

Received: 13 May 2019; Accepted: 5 June 2019; Published: 6 June 2019

\begin{abstract}
The black-banded oak borer, Coraebus florentinus, is an emerging pest of oak trees in the western Mediterranean region. Larvae of the insect are xylophagous and progressively excavate an annular gallery that interrupts sap flow, resulting in the death of the attacked branches. Until now, limited information has been available regarding the ecological interactions between C. florentinus and the main plant pathogenic fungi involved in the etiology of oak decline. Knowledge of these interactions is important in understanding their impact in natural ecosystems and developing appropriate management strategies. Therefore, in this study, we characterized the fungal communities occurring in the exoskeleton of adults and larvae of $C$. florentinus and associated with the necrotic wood tissues surrounding the branch galleries of declining oak trees. A total of 29 fungal species were identified based on DNA sequence data and morphological features, of which 14 were from symptomatic woody tissues, six from insect exoskeleton, and nine from both insects and symptomatic wood tissues. The most frequent fungal species, Cryphonectria naterciae (15.9\% of isolates), Dothiorella iberica $(11.3 \%)$, and Diplodia corticola $(9.9 \%)$, were isolated from both insect and gallery systems. All three species are well-known oak pathogens and are reported here, for the first time, to be associated with $C$. florentinus. At the same time, $89.6 \%$ of the fungal taxa were isolated from one or two sites, highlighting the site-dependence of fungal community assemblages.
\end{abstract}

Keywords: Buprestidae; wood-boring insect; emerging diseases; Botryosphaeriaceae; Diplodia corticola

\section{Introduction}

Over the past 30 years, Mediterranean oak forest ecosystems have been greatly impacted by severe decline phenomena and extensive mortality events, revealing the high vulnerability of these formations [1-3]. Severe decline and mortality events have the potential to drastically alter oak ecosystems, with important implications for the plant community dynamics, soil carbon-water balance, and structure and composition of soil food webs [4-7]. Oak decline is commonly considered a multifactorial disease in which many interacting abiotic and biotic factors such as drought, frost, insect pests and pathogens variable in intensity and frequency even at site level are involved [8-13]. Among the biotic factors involved in the onset of oak decline events, several invasive insects, fungi, and oomycetes play a primary role. In particular, the bark- and wood-boring beetles Coraebus florentinus Herbst, Coraebus undatus Fabricius, Cerambyx cerdo Linnaeus and Platypus cylindrus Fabricius are frequently implicated in oak declines in southern Europe [14-16]. At the same time, in recent years, 
many independent surveys have demonstrated the involvement of some canker-causing agents, such as Biscogniauxia mediterranea (De Not.) Kuntze and Diplodia corticola A.J.L. Phillips, A. Alves \& J. Luque, and root rot agents, such as Phytophthora cinnamomi Rands and Phytophthora quercina T. Jung, in the oak decline processes [17-20]. However, the ecological interactions between beetles and pathogenic fungi, as well as the role played by insects as a vector of the main fungal pathogens, are generally poorly investigated.

In recent decades, there has been a constant expansion of oak decline events in Sardinia, Italy, mainly in cork oak (Quercus suber L.) and holm oak (Quercus ilex L.) woodlands. Diplodia corticola and $P$. cinnamomi have been identified as the major pathogens involved [21,22]. Furthermore, the black-banded oak borer (Coraebus florentinus) is considered an emerging pest of oaks in Sardinia [23]. This xylophagous beetle attacks chestnut (Castanea sativa Miller) and both evergreen and deciduous oaks, with a particular affinity towards holm oak and cork oak trees [24]. The larvae of $C$. florentinus burrow into the branches forming elliptic galleries, resulting in the destruction of water- and sap-conducting tissues and consequent dieback of 6-8-year-old branches [25]. Along and surrounding the insect galleries, it is often possible to observe the presence of large necrotic lesions of woody tissues caused by fungal pathogens that may contribute to accelerating the branch death.

Therefore, given the growing recrudescence of oak decline events in Sardinian woodlands and the limited information about the ecological interactions among $C$. florentinus and plant pathogenic fungi, a study was carried out to isolate and identify the fungal species occurring in insect exoskeletons and associated with necrotic wood tissues surrounding gallery systems on the branches of declining oak trees.

\section{Materials and Methods}

\subsection{Study Sites, Field Surveys, and Sampling Procedure}

Six oak woodlands located in the central and northern part of Sardinia, Italy, where oak decline phenomena and attacks of C. florentinus were previously reported [23], were selected to collect living and just-emerged insects and symptomatic oak branches. In all woodlands, cork oak and/or holm oak were the dominant species, whereas pubescent oak (Quercus pubescens Willd.) was sporadically present in only two study areas, as seen in Table 1.

From autumn 2016 to spring 2017, oak trees that had been attacked by C. florentinus at each site were identified by the presence of bored branches (4-7 cm in diameter) showing dead leaves still attached scattered among healthy foliage (Figure 1). In order to evaluate the infestation level, in each study site, 3 transects of 10 trees each were traced, at random, inside the woodland. All oak plants along the transect have been identified at the species level (holm oak, cork oak, and pubescent oak) and the occurrence of damaged branches recorded. The infestation level was evaluated as the percentage of damaged trees among the total number of oak trees monitored.

A total of 133 bored branches were randomly collected from April to June 2017, prior to the emergence of adults (Table 1). Sampled branches were cut approximately $10 \mathrm{~cm}$ below the pupation chamber. The branches were debarked and cut to find larvae. Thirty-seven branches were stored in the laboratory in cages until the emergence of adults. The cages consisted of plastic cylinders $55 \mathrm{~cm}$ high and 30-40 cm in diameter, closed with two breathable metallic nets with small meshes to prevent adult exit. Cages were checked regularly to collect the adults of $C$. florentinus. As soon as the adults of $C$. florentinus escaped from branches, they were sexed by observing their abdomen and used for fungal isolation.

\subsection{Fungal Isolation and Identification}

Fungal isolation was achieved from insect exoskeletons of 37 adults (26 males and 11 females), from preimaginal insect stages (17 larvae), and from 133 necrotic woody tissues surrounding the insect gallery systems on oak branches (Figure 1). 
To avoid contamination, insects (adults and larvae) were sampled individually with sterilized tweezers, placed singly in an Eppendorf tube, and killed by freezing at $-20{ }^{\circ} \mathrm{C}$. For fungal isolation, insects were surface-disinfected for $2-3 \mathrm{sec}$ with ethanol (90\%), rinsed in sterile water, dried out on sterilized filter papers and then placed by pressing the whole bodies onto the surface of a potato dextrose agar (PDA, Oxoid Ltd., Basingstoke, UK) medium in $90 \mathrm{~mm}$ Petri dishes, using one insect per Petri dish.

Longitudinal and transverse sections were made to observe any internal symptoms (necrotic lesions) along the insect gallery system of branch samples. Isolations were achieved from approximately $5 \mathrm{~mm}^{2}$ chips of xylem tissues cut, aseptically, from the margin of necrotic lesions along galleries. All plant samples were cultured on PDA in $90 \mathrm{~mm}$ Petri dishes.

After incubation at $25^{\circ} \mathrm{C}$ for 1 week, all emerging mycelia from insects and plant material were subcultured to obtain pure cultures. Purified fungal isolates were subcultured onto half-strength PDA in $60 \mathrm{~mm}$ Petri dishes and kept on the laboratory bench at about $20-25^{\circ} \mathrm{C}$, where they received indirect sunlight to enhance sporulation. Fungal isolates were initially grouped and identified to genus/species level by comparison of macro- and micro-morphological features, such as colony appearance and size and shape of spores with species descriptions available in literature.

Representative isolates of each taxon were stored on PDA slants, under oil, in the culture collection of the Sez. di Patologia vegetale ed Entomologia, Dipartimento di Agraria at the University of Sassari.

Table 1. Study sites information and number of symptomatic branch samples collected from cork oak (c), holm oak (h), and pubescent oak (p) trees.

\begin{tabular}{cccccc}
\hline Study Sites & Locality & Elevation (m a.s.1.) & Coordinates $\left({ }^{\circ} \mathbf{N},{ }^{\circ}\right.$ E) & $\begin{array}{c}\text { Number of } \\
\text { Branches Sampled }\end{array}$ \\
\hline 1 & Gavoi & 710 & $40^{\circ} 07^{\prime} 43.6^{\prime \prime}$ & $9^{\circ} 11^{\prime} 14.1^{\prime \prime}$ & $0(\mathrm{c}), 13(\mathrm{~h}), 2(\mathrm{p})$ \\
2 & Buddusò & 780 & $40^{\circ} 34^{\prime} 01.4^{\prime \prime}$ & $9^{\circ} 19^{\prime} 06.9^{\prime \prime}$ & $19(\mathrm{c}), 11(\mathrm{~h}), 0(\mathrm{p})$ \\
3 & Pattada & 630 & $40^{\circ} 33^{\prime} 48.6^{\prime \prime}$ & $9^{\circ} 08^{\prime} 58.2^{\prime \prime}$ & $6(\mathrm{c}), 0(\mathrm{~h}), 0(\mathrm{p})$ \\
4 & Monte Lerno & 600 & $40^{\circ} 35^{\prime} 17.2^{\prime \prime}$ & $9^{\circ} 10^{\prime} 10.4^{\prime \prime}$ & $12(\mathrm{c}), 8(\mathrm{~h}), 0(\mathrm{p})$ \\
5 & Bottidda & 310 & $40^{\circ} 20^{\prime} 56.8^{\prime \prime}$ & $9^{\circ} 04^{\prime} 11.6^{\prime \prime}$ & $2(\mathrm{c}), 0(\mathrm{~h}), 0(\mathrm{p})$ \\
6 & Abbasanta & 370 & $40^{\circ} 08^{\prime} 28.9^{\prime \prime}$ & $8^{\circ} 45^{\prime} 40.1^{\prime \prime}$ & $60(\mathrm{c}), 0(\mathrm{~h}), 0(\mathrm{p})$ \\
\hline
\end{tabular}

\subsection{DNA Extraction, PCR Amplification, and Sequencing}

Molecular analysis was used to confirm the identification of all isolates at the species level. InstaGene Matrix (BioRad Laboratories, Hercules, CA, USA) was used to extract genomic DNA from 5-day-old cultures grown on PDA and incubated at $25^{\circ} \mathrm{C}$ in the dark. The primers ITS1 and ITS4 [26] were used to amplify and sequence the internal transcribed spacer (ITS) regions, including the complete 5.8s gene. Polymerase chain reaction (PCR) mixtures and amplification conditions were as described by Linaldeddu et al. [27]. The PCR products were purified using the EUROGOLD gel extraction kit (EuroClone S.p.A., Pero, Italy) following the manufacturer's instructions. The ITS regions were sequenced by the BMR Genomics DNA sequencing service (www.bmr-genomics.it), in both directions, with the primers used for amplification. The nucleotide sequences were read and edited with FinchTV 1.4.0 (Geospiza, Inc. http://www.geospiza.com/finchtv) and then compared with reference sequences (chiefly derived from type material) retrieved from GenBank using the BLAST search function [28]. Isolates were assigned to a species when their sequences were at least $99.8 \%$ identical to the sequence of type material or representative isolates. ITS sequences from representative isolates obtained in this study were deposited in GenBank (www.ncbi.nlm.nih.gov/genbank).

\subsection{Data Analysis}

The species diversity of the insect-associated fungal communities was measured using the taxonomic richness (S), Shannon diversity index (H), and Simpson dominance index (D) [29]. In addition, the similarity of fungal communities between insect exoskeletons and gallery systems was evaluated 
using the Jaccard similarity coefficient $(\mathrm{Jc})$ [30]. The species diversity analyses were performed using the software Past ${ }^{\circledR}$ version 3.24 [31].

Similarities in fungal taxonomic richness between communities were summarized in Venn diagrams using GeneVenn software (http://genevenn.sourceforge.net/).
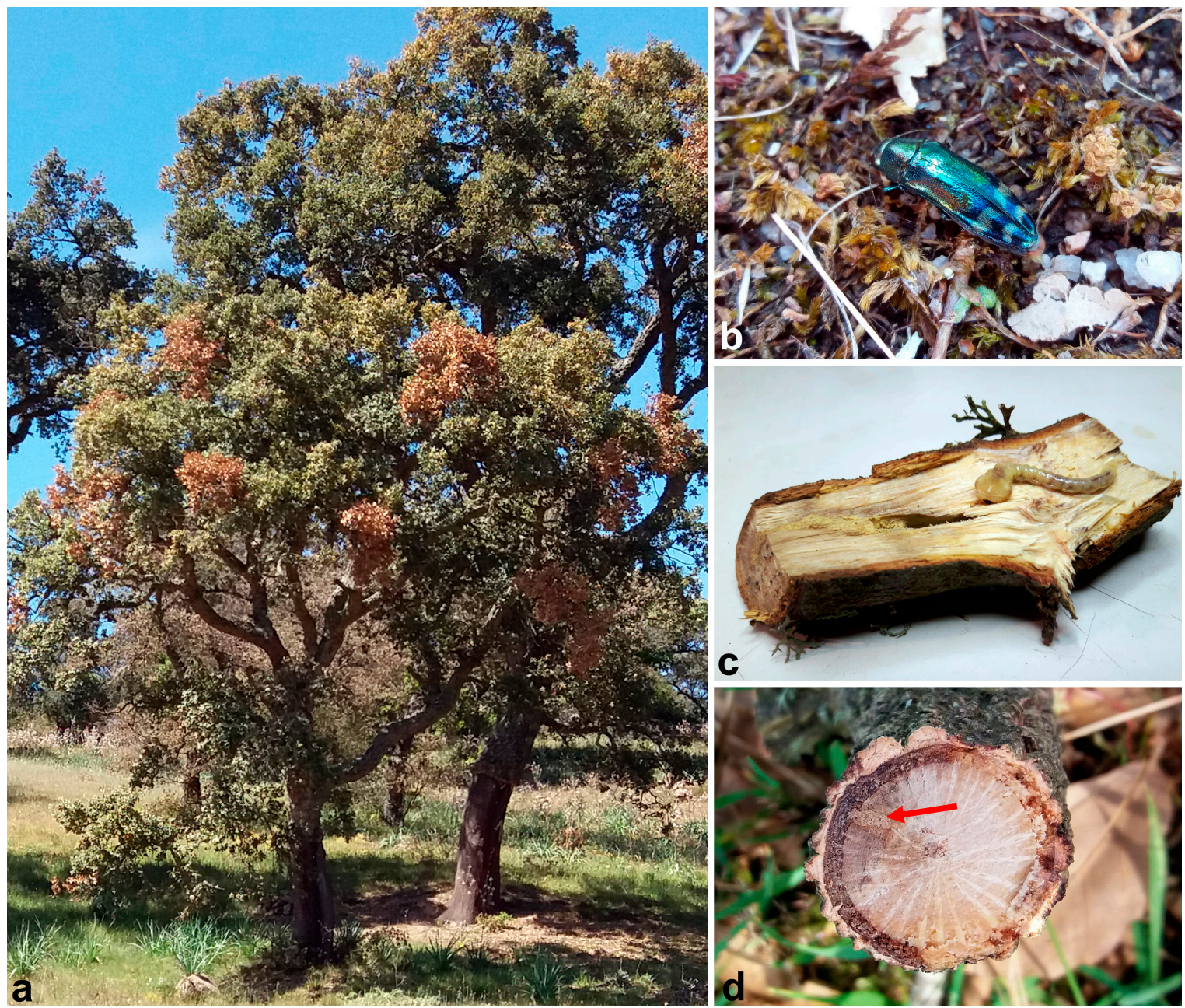

Figure 1. Cork oak tree showing multiple branch dieback symptoms (a), adult and larvae of Coraebus florentinus $(\mathbf{b}, \mathbf{c})$, and necrotic wood tissues surrounding the beetle gallery (red arrow) on a cork oak branch $(\mathbf{d})$.

\section{Results}

\subsection{Field Survey}

Insect infestation was very variable among the investigated sites (Table 2). The most infested woodland was site 6 . This woodland is chiefly composed of cork oak trees (87\%) and, to a lesser extent, by pubescent oak trees (13\%). At this site, $86.7 \%$ of oaks were attacked by the buprestid pest C. florentinus, with an average of 5.5 bored branches per tree.

A severe infestation level was also recorded in the mixed oak woodland of site 4 (10\% holm oaks, $87 \%$ cork oaks, $3 \%$ pubescent oaks) and 1 (63\% holm oaks, $27 \%$ cork oaks, $10 \%$ pubescent oaks), with an average number of bored branches of 2.6 and 4.8 , respectively.

At the other sites, the infestation level ranged from $3.3 \%$ to $43.3 \%$, with an average number of bored branches per tree that ranged from 1.5 to 2 (Table 2). 
Table 2. Coraebus florentinus infestation level (\%) recorded at the study sites.

\begin{tabular}{cccccc}
\hline Study Sites & Locality & $\begin{array}{c}\mathbf{N}^{\circ} \text { of oak Tree } \\
\text { Monitored }\end{array}$ & $\begin{array}{c}\mathbf{N}^{\circ} \text { of Tree } \\
\text { Damaged }\end{array}$ & $\begin{array}{c}\text { Infestation } \\
\text { Level (\%) }\end{array}$ & $\begin{array}{c}\text { Bored Branches per } \\
\text { Tree (Mean } \pm \text { SD) }\end{array}$ \\
\hline 1 & Gavoi & 30 & 20 & 66.7 & $4.8 \pm 3.9$ \\
2 & Buddusò & 30 & 13 & 43.3 & $1.7 \pm 1.1$ \\
3 & Pattada & 30 & 4 & 13.3 & $1.5 \pm 0.6$ \\
4 & Monte Lerno & 30 & 23 & 76.7 & $2.6 \pm 2.2$ \\
5 & Bottidda & 30 & 1 & 3.3 & 2 \\
6 & Abbasanta & 30 & 26 & 86.7 & $5.5 \pm 3.9$ \\
\hline
\end{tabular}

\subsection{Fungal Isolation}

Isolations carried out from insect exoskeletons and symptomatic branch samples yielded a total of 151 fungal colonies belonging to 12 orders, including Ascomycetes, Basidiomycetes, and Zygomycetes. About a quarter of the isolates (24.5\%) were included within the Botryosphaeriales order, followed by Pleosporales (23.8\%) and Diaporthales (21.2\%); the remaining isolates were distributed across nine orders.

A total of 26 genera belonging to 19 families were identified. Botryosphaeriaceae, Cryphonectriaceae, and Pleosporaceae were the most abundant taxonomic groups, with 37, 24, and 21 isolates, respectively.

A total of 29 fungal species were identified based on DNA sequence data and morphological features, of which 14 were from symptomatic woody tissues, 6 from insect exoskeletons, and 9 from both insects and symptomatic wood tissues taken from bored branches (Tables 3 and 4). The most frequent fungal isolates, with a value of $15.9 \%$, were identified as Cryphonectria naterciae Bragança, E. Diogo \& A.J.L. Phillips. The second most frequent species corresponded to Dothiorella iberica A.J.L. Phillips, J. Luque \& A. Alves, representing $11.3 \%$ of isolates, followed by Diplodia corticola, with a value of $9.9 \%$ (Table 4). The other taxa were represented by a limited number of isolates.

Nine fungal species, namely Alternaria doliconidium J.F. Li, Camporesi \& K.D. Hyde, Alternaria hordeicola E.G. Simmons \& Kosiak, Botrytis cinerea Pers., C. naterciae, D. corticola, Do. iberica, Gnomoniopsis paraclavulata Sogonov, Penicillium sp., and Trichoderma harzianum Rifai, were isolated from both insect exoskeletons and symptomatic woody tissues of oak branches (Table 4). Interestingly, the species Do. iberica and C. naterciae were isolated from adult males, whereas D. corticola was isolated from the females. Alternaria doliconidium, A. hordeicola, and Penicillium sp. were the only species isolated from both adults and larvae.

Table 3. Percentage of internal transcribed spacer (ITS) sequence identity between representative isolates of each species obtained in this study and their closest matching references in GenBank.

\begin{tabular}{|c|c|c|c|c|c|}
\hline \multirow[b]{2}{*}{ Fungal taxa (Strain Number) } & \multirow[b]{2}{*}{$\begin{array}{c}\text { Accession } \\
\text { Number }\end{array}$} & \multicolumn{4}{|c|}{ The Closest Matching NCBI GenBank Entry } \\
\hline & & Taxon & $\begin{array}{c}\text { Accession } \\
\text { Number }\end{array}$ & (\%) Identity & References \\
\hline Alternaria hordeicola (cp72.1) & MK796129 & Alternaria hordeicola* & NR_136019 & $100 \%$ & [33] \\
\hline Arthrinium sp. (cp62.2) & MK796130 & Arthrinium kogelbergense* & KF144892 & $96.1 \%$ & [34] \\
\hline Aureobasidium pullulans (cp73.2) & MK796131 & Aureobasidium pullulans* & FJ150906 & $100 \%$ & [35] \\
\hline Botrytis cinerea (cp67) & MK796134 & Botrytis cinerea & MH860108 & $100 \%$ & [38] \\
\hline Cladosporium sp. $\S$ & & & & & \\
\hline Cryphonectria naterciae (cp71.1) & MK796135 & Cryphonectria naterciae* & NR_159875 & $100 \%$ & [39] \\
\hline Cryptovalsa ampelina (cp12) & MK796136 & Cryptovalsa ampelina & JN975335 & $100 \%$ & [40] \\
\hline Cytospora sp. (cp68.2) & MK796137 & Cytospora fraxinigena* & MF190134 & $99.04 \%$ & [41] \\
\hline Gnomoniopsis paraclavulata (cp71.5) & MK796142 & Gnomoniopsis paraclavulata* & EU254839 & $100 \%$ & {$[45]$} \\
\hline Kalmusia sp. (cp46) & MK796143 & Kalmusia variispora* & NR_145165 & $99.6 \%$ & [46] \\
\hline Neocucurbitaria cava (cp75.3) & MK796144 & Neocucurbitaria cava & AY853248 & $100 \%$ & [47] \\
\hline Neonectria coccinea (cp70) & MK796145 & Neonectria coccinea* & KC660521 & $99.81 \%$ & [48] \\
\hline Nigrospora osmanthi (cp22) & MK796146 & Nigrospora osmanthi* & KX986010 & $99.79 \%$ & [49] \\
\hline
\end{tabular}


Table 3. Cont.

\begin{tabular}{|c|c|c|c|c|c|}
\hline \multirow[b]{2}{*}{ Fungal taxa (Strain Number) } & \multirow[b]{2}{*}{$\begin{array}{c}\text { Accession } \\
\text { Number }\end{array}$} & \multicolumn{4}{|c|}{ The Closest Matching NCBI GenBank Entry } \\
\hline & & Taxon & $\begin{array}{c}\text { Accession } \\
\text { Number }\end{array}$ & (\%) Identity & References \\
\hline Phaeoacremonium angustius (cp77.3) & MK796147 & Phaeoacremonium angustius* & KU060813 & $100 \%$ & [50] \\
\hline Pseudocamarosporium piceae (cp48) & MK796148 & Pseudocamarosporium piceae & KJ747046 & $100 \%$ & [51] \\
\hline Querciphoma carteri (cp53) & MK796149 & Querciphoma carteri & KF251209 & $100 \%$ & [52] \\
\hline Stereum armeniacum (cp35) & MK796152 & Stereum armeniacum ${ }^{*}$ & MH862626 & $100 \%$ & [38] \\
\hline Trichoderma harzianum (cp25) & MK796153 & Trichoderma harzianum & MH865862 & $100 \%$ & [38] \\
\hline Unidentified (Mortierellales) (cp91.1) & MK796154 & Mortierella hyalina & HQ630355 & $82 \%$ & [54] \\
\hline
\end{tabular}

$\S$ Not sequenced. * From ex-type culture.

Among the most frequently recovered species, Do. iberica was isolated from the galleries of all three oak species examined, while C. naterciae and D. corticola were only isolated from cork oak trees. Dothiorella iberica and C. naterciae were the most widespread species, and positive samples were derived from four of the six examined sites. Interestingly, $89.6 \%$ of the taxa were isolated from one or two sites.

No significant matches were generated in the BLAST analysis for the sequence of the zygomycetous strain and, hence, it was not identified to a species and genus level (Table 3).

Table 4. Number of fungal isolates obtained from insects and wood tissues of bored oak branches.

\begin{tabular}{|c|c|c|c|c|c|c|}
\hline \multirow{2}{*}{ Fungal taxa } & \multirow{2}{*}{ Ecology * } & \multicolumn{2}{|c|}{ Adults } & \multirow{2}{*}{ Larvae } & \multirow{2}{*}{ Wood Tissues } & \multirow{2}{*}{ Number of Sites } \\
\hline & & Male & Female & & & \\
\hline Alternaria doliconidium & unk & 1 & & 2 & 3 & 1 \\
\hline Alternaria hordeicola & unk & 8 & & 3 & 2 & 1 \\
\hline Arthrinium sp. & unk & & & & 1 & 1 \\
\hline Aureobasidium pullulans & ocr & & & & 8 & 1 \\
\hline Biscogniauxia rosacearum & $\mathrm{pp}$ & & & & 3 & 1 \\
\hline Botryosphaeria dothidea & $\mathrm{pp}$ & & & & 5 & 2 \\
\hline Botrytis cinerea & $\mathrm{pp}$ & & & 1 & 2 & 2 \\
\hline Cladosporium sp. & unk & & & & 1 & 1 \\
\hline Cryphonectria naterciae & $\mathrm{pp}$ & 5 & & & 19 & 4 \\
\hline Cryptovalsa ampelina & $\mathrm{pp}$ & & & & 1 & 1 \\
\hline Cytospora sp. & unk & & & & 1 & 1 \\
\hline Diatrype sp. & unk & & & & 5 & 2 \\
\hline Diplodia corticola & $\mathrm{pp}$ & & 5 & & 10 & 1 \\
\hline Dothiorella iberica & $\mathrm{pp}$ & 1 & & & 16 & 4 \\
\hline Fusarium sp. & unk & & & 6 & & 1 \\
\hline Gnomoniopsis paraclavulata & unk & & & 1 & 6 & 2 \\
\hline Kalmusia sp. & unk & & & & 2 & 1 \\
\hline Neocucurbitaria cava & $\mathrm{pp}$ & 7 & 4 & & & 1 \\
\hline Neonectria coccinea & $\mathrm{pp}$ & & & 5 & & 2 \\
\hline Nigrospora osmanthi & unk & & & & 2 & 1 \\
\hline Penicillium sp. & unk & 1 & & 1 & 1 & 1 \\
\hline Phaeoacremonium angustius & $\mathrm{pp}$ & 2 & & & & 1 \\
\hline Pseudocamarosporium piceae & ocr & & & & 1 & 1 \\
\hline Querciphoma carteri & unk & & & & 1 & 1 \\
\hline Stemphylium amaranthi & $\mathrm{pp}$ & & & & 1 & 1 \\
\hline Stemphylium vesicarium & pp & 1 & & & & 1 \\
\hline Stereum armeniacum & ocr & & & & 1 & 1 \\
\hline Trichoderma harzianum & ocr & & 1 & & 3 & 3 \\
\hline Unidentified Mortierellales & unk & & 1 & & & 1 \\
\hline
\end{tabular}

${ }^{*}$ Ecology: pp = plant pathogen; ocr = other ecological roles; unk = no data about ecology available. 


\subsection{Fungal Community Diversity}

The Shannon diversity index value was highest for the fungal community associated with symptomatic wood tissues surrounding feeding galleries on oak branches (Table 5). For both communities (insect and wood tissues), low values of the Simpson dominance index were measured, demonstrating that both communities had a high microbial diversity and richness. The Simpson dominance index was slightly higher in insects than the gallery systems community.

Table 5. Diversity indices of fungal communities.

\begin{tabular}{ccc}
\hline Index & Insect & Wood Tissues \\
\hline Taxonomic richness & 15 & 23 \\
Shannon diversity index & 2.352 & 2.636 \\
Simpson dominance index & 0.119 & 0.101 \\
Jaccard similarity coefficient * & \multicolumn{2}{c}{0.31} \\
\hline
\end{tabular}

* Between fungal community of insect and wood tissues.

The Jaccard similarity coefficient showed a low similarity value between insect and plant fungal communities, indicating that only a few fungal species could be efficiently vectored by $C$. florentinus (Table 5). The highest overlap (Jc $=0.259$ ) was observed for the fungal communities from adults and wood tissues, indicating that many of the isolated fungi are not essential for larvae development (Figure 2).

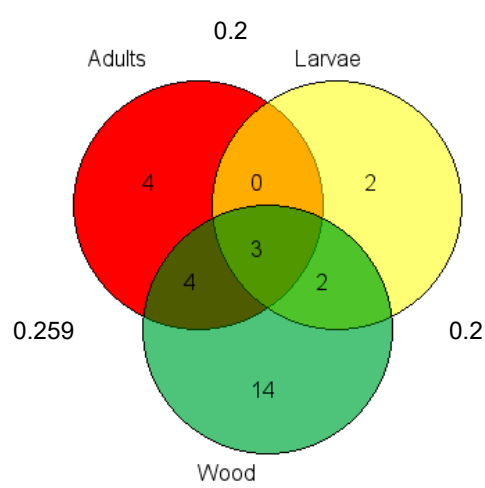

Figure 2. Venn diagram illustrating the unique and shared fungal taxa among insect adults (red), larvae (yellow), and wood tissues (green). Outside numbers are the Jaccard similarity coefficient.

\section{Discussion}

The findings obtained in this study allowed us to characterize, for the first time, the fungal communities associated with $C$. florentinus attacks in declining oak woodlands in Sardinia, contributing to expanding the knowledge on the bioecology of this emerging insect pest in the Mediterranean region. Coraebus florentinus is an insect pest able to attack apparently healthy plants and cause extensive wilting and branch dieback, which contribute to a general and progressive decline of oak trees [24,55]. After mating in summer, C. florentinus females lay eggs in the bark of twigs and after about 2 weeks, emerging larvae feed in the inner bark, burrowing downward sinuous galleries in the sapwood [25]. The results of this study show that the feed gallery system excavated by the insect represents a substrate on which several pathogenic fungi can develop, causing necrotic lesions.

In this study, a total of 29 fungal species were isolated from six different sites located across northern and central Sardinia. In particular, three of the main oak canker-causing agents, namely Diplodia corticola, Dothiorella iberica, and Cryphonectria naterciae, were isolated from bored branches.

D. corticola has emerged as an aggressive and potentially invasive fungal pathogen in southern Europe, North Africa, and North America [18,56-58]. The frequency of its attacks on oak trees 
has significantly increased over the past decades, especially in mature cork oak forests after cork extraction $[59,60]$. Diplodia corticola is a necrotrophic pathogen whose infections induce extensive inner bark and xylem necrosis associated with blackish exudation from the outer bark [61]. Despite the various studies conducted on this emerging pathogen, the forces driving spore dissemination remain poorly understood. Recently, Inácio et al. [62] have demonstrated that P. cylindrus is a vector of D. corticola, whereas Kostovcik et al. [63] found that D. corticola is one of the fungi most frequently isolated from the mycangia of Xyleborus affinis Eichhoff and Xylosandrus crassiusculus Motschulsky, two invasive ambrosia beetles in Florida. In this study, D. corticola was the second most abundant species obtained from the exoskeleton of $C$. florentinus females, and the third most abundant from the woody tissues of bored oak branches. Interestingly, D. corticola was only isolated at site 6 , which was characterized by the highest infestation level of C. florentinus.

The species of Dothiorella are considered weak pathogens or endophytes of different woody plants worldwide [64]; however, some species, such as Do. iberica, can cause branch cankers on oak trees $[65,66]$. In this study, Do. iberica was the second most abundant species obtained from necrotic tissues along the insect gallery systems.

Isolates of $C$. naterciae dominated the beetle-associated fungal communities in our investigation. C. naterciae was originally described from cork oak and sweet chestnut in Portugal [39], and was recently reported to be a cork oak pathogen in Algeria by Shami et al. [58]. To date, little information is available about the geographic distribution, oak host range, and bioecology of this species. All three species, D. corticola, Do. iberica, and C. naterciae are here reported for the first time, to be associated with C. florentinus.

Attacks of plant pathogenic fungi and xylophagous beetles are often found together on declining oak trees. A recent investigation on the causes underlying the severe decline of coast live oak (Quercus agrifolia Née) trees in Californian woodlands demonstrated the co-occurrence of D. corticola, Do. iberica, and the goldspotted oak borer (Agrilus auroguttatus Schaeffer), an emerging Buprestid species, at several infested sites [65]. Furthermore, it has been demonstrated that exit holes produced by cerambycid pests could represent a mode of entry for opportunistic pathogens such as B. mediterranea [15], a fungal species frequently recovered from declining oak trees [67]. Interestingly, in this study, the species Biscogniauxia rosacearum M.L. Raimondo \& Carlucci, a recently described pathogen known to occur only on rosaceous hosts [36], was isolated from insect gallery systems.

The insect-associated fungal communities obtained in this study seem to be influenced by site factors, given that the majority of the species were sporadic and were isolated from a single site. Lynch et al. [68] obtained similar results when studying the occurrence and incidence of fungal species in declining coast live oak trees infested by A. auroguttatus in California.

\section{Conclusions}

In conclusion, the findings obtained in this study highlight that $C$. florentinus plays a role in the diffusion of different plant-pathogenic fungi and, in particular, of D. corticola; one of the main fungal pathogens involved in the etiology of oak decline in southwestern Europe and North America. Therefore, in addition to ambrosia beetles and cerambycid pests, Buprestid species such as C. florentinus could also contribute to fungal dispersal and influence fungal community assembly in declining oak ecosystems.

Whether the fungal species isolated in this study can promote the attacks of $C$. florentinus remains to be clarified, but the combined effect of $C$. florentinus and D. corticola on Mediterranean oak ecosystems could have a strong ecological impact, as recently observed in Spain by Torres-Vila et al. [55]. The co-occurrence of multiple adverse factors in the oak decline onset, such as C. florentinus and D. corticola, together with inappropriate agroforestry activity [69] and climatic change [70], suggest that a multidisciplinary approach is essential for developing adequate management strategies to preserve these important and vulnerable ecosystems in the future. 
Author Contributions: C.P., A.L. and B.T.L. conceptualization; C.P. and V.D. field survey and sample collection; C.P., V.D., L.M. (Lucia Maddau) and B.T.L. laboratory analysis and data elaboration; A.L., B.T.L. and L.M. (Lucio Montecchio) funding acquisition; B.T.L. draft writing; A.L., L.M. (Lucia Maddau) and L.M. (Lucio Montecchio) review and manuscript editing.

Funding: This research was funded by by Regione Autonoma della Sardegna, Assessorato della Difesa dell'Ambiente through a scientific-technical collaboration agreement.

Conflicts of Interest: The authors declare no conflict of interest.

\section{References}

1. Brasier, C.M. Oak tree mortality in Iberia. Nature 1992, 360, 539. [CrossRef]

2. Sallé, A.; Nageleisen, L.M.; Lieutier, F. Bark and wood boring insects involved in oak declines in Europe: Current knowledge and future prospects in a context of climate change. For. Ecol. Manag. 2014, 328, 79-93. [CrossRef]

3. Moricca, S.; Linaldeddu, B.T.; Ginetti, B.; Scanu, B.; Franceschini, A.; Ragazzi, A. Endemic and Emerging Pathogens Threatening Cork Oak Trees: Management Options for Conserving a Unique Forest Ecosystem. Plant Dis. 2016, 100, 2183-2193. [CrossRef] [PubMed]

4. Gómez-Aparicio, L.; Ibáñez, B.; Serrano, M.S.; De Vita, P.; Ávila, J.M.; Pérez-Ramos, I.M.; García, L.V.; Sánchez, M.E.; Marañón, T. Spatial patterns of soil pathogens in declining Mediterranean forests: Implications for tree species regeneration. New Phytol. 2012, 194, 1014-1024. [CrossRef] [PubMed]

5. Haavik, L.J.; Billings, S.A.; Guldin, J.M.; Stephen, F.M. Emergent insects, pathogens and drought shape changing patterns in oak decline in North America and Europe. For. Ecol. Manag. 2015, 354, 190-205. [CrossRef]

6. Domínguez-Begines, J.; De Deyn, G.B.; García, L.V.; Eisenhauer, N.; Gómez-Aparicio, L. Cascading spatial and trophic impacts of oak decline on the soil food web. J. Ecol. 2018, 107, 1199-1214. [CrossRef]

7. Avila, J.M.; Gallardo, A.; Gómez-Aparicio, L. Pathogen-induced tree mortality interacts with predicted climate change to alter soil respiration and nutrient availability in Mediterranean systems. Biogeochemistry 2019, 142, 53-71. [CrossRef]

8. Ghobad-Nejhad, M.; Meyn, R.; Langer, E. Endophytic fungi isolated from healthy and declining Persian oak (Quercus brantii) in western Iran. Nova Hedwig. 2018, 107, 273-290. [CrossRef]

9. Moreira, A.C.; Martins, J.M.S. Influence of site factors on the impact of Phytophthora cinnamomi in cork oak stands in Portugal. For. Pathol. 2005, 35, 145-162. [CrossRef]

10. Henriques, J.; Inácio, M.L.; Sousa, E. Ambrosia fungi in the insect-fungi symbiosis in relation to cork oak decline. Rev. Iberoam. Micol. 2006, 23, 185-188. [CrossRef]

11. Linaldeddu, B.T.; Franceschini, A.; Alves, A.; Phillips, A.J. Diplodia quercivora sp. nov.: A new species of Diplodia on declining Quercus canariensis trees in Tunisia. Mycologia 2013, 105, 1266-1274. [CrossRef] [PubMed]

12. Camilo-Alves, C.S.P.; Clara, M.I.E.; Ribeiro, N.M.C.A. Decline of Mediterranean oak trees and its association with Phytophthora cinnamomi: A review. Eur. J. For. Res. 2013, 132, 411-432. [CrossRef]

13. Tiberi, R.; Branco, M.; Bracalini, M.; Croci, F.; Panzavolta, T. Cork oak pests: A review of insect damage and management. Ann. For. Sci. 2016, 73, 219-232. [CrossRef]

14. Cao, O.V.; Luciano, P. Severe infestations of Platypus cylindrus Fabricius (Coleoptera Platypodidae) in Sardinian cork oak forests. IOBC/WPRS Bull. 2005, 28, 145-146.

15. Martín, J.; Cabezas, J.; Buyolo, T.; Paton, D. The relationship between Cerambyx spp. damage and subsequent Biscogniauxia mediterranum infection on Quercus suber forests. For. Ecol. Manag. 2005, 216, 166-174. [CrossRef]

16. Gallardo, A.; Jiménez, A.; Antonietty, C.A.; Villagrán, M.; Ocete, M.E.; Soria, F.J. Forecasting infestation by Coraebus undatus (Coleoptera, Buprestidae) in cork oak forests. Int. J. Pest Manag. 2012, 58, 275-280. [CrossRef]

17. Mirabolfathy, M.; Groenewald, J.Z.; Crous, P.W. The occurrence of charcoal disease caused by Biscogniauxia mediterranea on chestnut-leaved oak (Quercus castaneifolia) in the Golestan Forests of Iran. Plant Dis. 2011, 95, 876. [CrossRef] [PubMed]

18. Linaldeddu, B.T.; Maddau, L.; Franceschini, A. First report of Diplodia corticola causing canker and dieback of Quercus ilex, Q. petraea and Q. suber in Corsica (France). Plant Dis. 2017, 101, 256. [CrossRef] 
19. Català, S.; Berbegal, M.; Pérez-Sierra, A.; Abad-Campos, P. Metabarcoding and development of new real-time specific assays reveal Phytophthora species diversity in holm oak forests in eastern Spain. Plant Pathol. 2016, 66, 115-123. [CrossRef]

20. Frisullo, S.; Lima, G.; Magnano di San Lio, G.; Camele, I.; Melissano, L.; Puglisi, I.; Pane, A.; Agosteo, G.E.; Prudente, L.; Cacciola, S.O. Phytophthora cinnamomi Involved in the Decline of Holm Oak (Quercus ilex) Stands in Southern Italy. For. Sci. 2018, 64, 290-298. [CrossRef]

21. Franceschini, A.; Corda, P.; Maddau, L.; Marras, F. Observations sur Diplodia mutila, pathogene du chêne-liege en Sardaigne. IOBC/WPRS Bull. 1999, 22, 5-12.

22. Linaldeddu, B.T.; Scanu, B.; Maddau, L.; Franceschini, A. Diplodia corticola and Phytophthora cinnamomi: The main pathogens involved in holm oak decline on Caprera Island (Italy). For. Pathol. 2014, 44, 191-200. [CrossRef]

23. Luciano, P.; Lentini, A.; Cao, O.V. Gravi danni da Coroebus florentinus in sugherete sarde. Notiziario sulla protezione delle piante $2007,21,215-217$.

24. Jurc, M.; Bojović, S.; Komjanc, B.; Krč, J. Xylophagous entomofauna in branches of oaks (Quercus spp.) and its significance for oak health in the Karst region of Slovenia. Biologia 2009, 64, 130-138. [CrossRef]

25. Cárdenas, A.M.; Gallardo, P. The effect of temperature on the preimaginal development of the Jewel beetle, Coraebus florentinus (Coleoptera: Buprestidae). Eur. J. Entomol. 2012, 109, 21-28. [CrossRef]

26. White, T.J.; Bruns, T.; Lee, S.; Taylor, J. Amplification and direct sequencing of fungal ribosomal RNA genes for phylogenies. In PCR Protocols: A Guide to Methods and Applications; Innis, M.A., Gelfand, D.H., Sninsky, J.J., White, T.J., Eds.; Academic Press: San Diego, CA, USA, 1990; pp. 315-322. ISBN 9780123721815.

27. Linaldeddu, B.T.; Alves, A.; Phillips, A.J.L. Sardiniella urbana gen. et sp. nov., a new member of the Botryosphaeriaceae isolated from declining Celtis australis trees in Sardinian streetscapes. Mycosphere 2016, 7, 893-905. [CrossRef]

28. Altschul, S.F.; Gish, W.; Miller, W.; Myers, E.W.; Lipman, D.J. Basic local alignment search tool. J. Mol. Biol. 2010, 215, 403-410. [CrossRef]

29. Morris, E.K.; Caruso, T.; Buscot, F.; Fischer, M.; Hancock, C.; Maier, T.S. Choosing and using diversity indices: Insights for ecological applications from the German biodiversity Exploratories. Ecol. Evol. 2014, 4, 3514-3524. [CrossRef]

30. Jaccard, P. The distribution of the flora in the alpine zone. New Phytol. 1912, 11, 37-50. [CrossRef]

31. Hammer, Ø.; Harper, D.A.T.; Ryan, P.D. Past: Paleontological Statistics Software Package for Education and Data Analysis. Palaeontol. Electron. 2001, 4, 9.

32. Wanasinghe, D.N.; Phukhamsakda, C.; Hyde, K.D.; Jeewon, R.; Lee, H.B.; Jones, E.G.; Tibpromma, S.; Tennakoon, D.S.; Dissanayake, A.J.; Jayasiri, S.C.; et al. Fungal diversity notes 709-839: Taxonomic and phylogenetic contributions to fungal taxa with an emphasis on fungi on Rosaceae. Fungal Divers. 2018, 89, 1-236. [CrossRef]

33. Kwaśna, H.; Ward, E.; Kosiak, B. Lewia hordeicola sp. nov. from barley grain. Mycologia 2006, 98, 662-668. [CrossRef]

34. Crous, P.W.; Groenewald, J.Z. A phylogenetic re-evaluation of Arthrinium. IMA Fungus 2013, 4, $133-154$. [CrossRef] [PubMed]

35. Zalar, P.; Gostinčar, C.; De Hoog, G.S.; Uršič, V.; Sudhadham, M.; Gunde-Cimerman, N. Redefinition of Aureobasidium pullulans and its varieties. Stud. Mycol. 2008, 61, 21-38. [CrossRef] [PubMed]

36. Raimondo, M.L.; Lops, F.; Carlucci, A. Charcoal canker of pear, plum, and quince trees caused by Biscogniauxia rosacearum sp. nov. in Southern Italy. Plant Dis. 2016, 100, 1813-1822. [CrossRef] [PubMed]

37. Slippers, B.; Crous, P.W.; Denman, S.; Coutinho, T.A.; Wingfield, B.D.; Wingfield, M.J. Combined multiple gene genealogies and phenotypic characters differentiate several species previously identified as Botryosphaeria dothidea. Mycologia 2004, 96, 83-101. [CrossRef]

38. Vu, D.; Groenewald, M.; de Vries, M.; Gehrmann, T.; Stielow, B.; Eberhardt, U.; Al-Hatmi, A.; Groenewald, J.Z.; Cardinali, G.; Houbraken, J.; et al. Large-scale generation and analysis of filamentous fungal DNA barcodes boosts coverage for kingdom fungi and reveals thresholds for fungal species and higher taxon delimitation. Stud. Mycol. 2019, 92, 135-154. [CrossRef]

39. Braganca, H.; Rigling, D.; Diogo, E.; Capelo, J.; Phillips, A.; Tenreiro, R. Cryphonectria naterciae: A new species in the Cryphonectria-Endothia complex and diagnostic molecular markers based on microsatellite-primed PCR. Fungal Biol. 2011, 115, 852-861. [CrossRef] 
40. Luque, J.; Garcia-Figueres, F.; Legorburu, F.J.; Muruamendiaraz, A.; Armengol, J.; Trouillas, F.P. Species of Diatrypaceae associated with grapevine trunk diseases in Eastern Spain. Phytopathol. Mediterr. 2012, 51, 528-540. [CrossRef]

41. Senanayake, I.C.; Crous, P.W.; Groenewald, J.Z.; Maharachchikumbura, S.S.N.; Jeewon, R.; Phillips, A.J.L.; Bhat, J.D.; Perera, R.H.; Li, Q.R.; Li, W.J.; et al. Families of Diaporthales based on morphological and phylogenetic evidence. Stud. Mycol. 2017, 86, 217-296. [CrossRef]

42. Lawrence, D.P.; Travadon, R.; Nita, M.; Baumgartner, K. TrunkDiseaseID. org: A molecular database for fast and accurate identification of fungi commonly isolated from grapevine wood. Crop Prot. 2017, 102, 110-117. [CrossRef]

43. Alves, A.; Correia, A.; Luque, J.; Phillips, A.J.L. Botryosphaeria corticola, sp. nov. on Quercus species, with notes and description of Botryosphaeria stevensii and its anamorph, Diplodia mutila. Mycologia 2004, 96, 598-613. [CrossRef]

44. Phillips, A.J.L.; Alves, A.; Correia, A.; Luque, J. Two new species of Botryosphaeria with brown, 1-septate ascospores and Dothiorella anamorphs. Mycologia 2005, 97, 513-529. [CrossRef] [PubMed]

45. Sogonov, M.V.; Castlebury, L.A.; Rossman, A.Y.; Mejía, L.C.; White, J.F. Leaf-inhabiting genera of the Gnomoniaceae, Diaporthales. Stud. Mycol. 2008, 62, 1-77. [CrossRef] [PubMed]

46. Ariyawansa, H.A.; Tanaka, K.; Thambugala, K.M.; Phookamsak, R.; Tian, Q.; Camporesi, E.; Hongsanan, S.; Monkai, J.; Wanasinghe, D.N.; Chukeatirote, E.; et al. A molecular phylogenetic reappraisal of the Didymosphaeriaceae (=Montagnulaceae). Fungal Divers. 2014, 68, 69-104. [CrossRef]

47. Valenzuela-Lopez, N.; Cano-Lira, J.F.; Guarro, J.; Sutton, D.A.; Wiederhold, N.; Crous, P.W.; Stchigel, A.M. Coelomycetous Dothideomycetes with emphasis on the families Cucurbitariaceae and Didymellaceae. Stud. Mycol. 2018, 90, 1-69. [CrossRef] [PubMed]

48. Hirooka, Y.; Rossman, A.Y.; Zhuang, W.Y.; Salgado-Salazar, C.; Chaverri, P. Species delimitation for Neonectria coccinea group including the causal agents of beech bark disease in Asia, Europe, and North America. Mycosystema 2013, 32, 485-517.

49. Wang, M.; Liu, F.; Crous, P.W.; Cai, L. Phylogenetic reassessment of Nigrospora: Ubiquitous endophytes, plant and human pathogens. Persoonia 2017, 39, 118-142. [CrossRef]

50. Réblová, M.; Jaklitsch, W.M.; Réblová, K.; Štěpánek, V. Phylogenetic Reconstruction of the Calosphaeriales and Togniniales Using Five Genes and Predicted RNA Secondary Structures of ITS, and Flabellascus tenuirostris gen. et sp. nov. PLoS ONE 2015, 10, e0144616. [CrossRef]

51. Wijayawardene, N.N.; Hyde, K.D.; Bhat, D.J.; Camporesi, E.; Schumacher, R.K.; Thilini Chethana, K.W.; Wikee, S.; Bahkali, A.H.; Wang, Y. Camarosporium-like species are polyphyletic in Pleosporales; introducing Paracamarosporium and Pseudocamarosporium gen. nov. in Montagnulaceae. Cryptogam. Mycol. 2014, 35, 177-198. [CrossRef]

52. Crous, P.W.; Groenewald, J.Z. The Genera of Fungi-G 4: Camarosporium and Dothiora. IMA Fungus 2017, 8, 131-152. [CrossRef] [PubMed]

53. Woudenberg, J.H.C.; Hanse, B.; van Leeuwen, G.C.M.; Groenewald, J.Z.; Crous, P.W. Stemphylium revisited. Stud. Mycol. 2017, 87, 77-103. [CrossRef] [PubMed]

54. Nagy, L.G.; Petkovits, T.; Kovács, G.M.; Voigt, K.; Vágvölgyi, C.; Papp, T. Where is the unseen fungal diversity hidden? A study of Mortierella reveals a large contribution of reference collections to the identification of fungal environmental sequences. New Phytol. 2011, 191, 789-794. [CrossRef] [PubMed]

55. Torres-Vila, L.M.; Echave-Sanabria, A.C.; Mendiola-Díaz, F.J.; Moral-García, F.J. Mapping oak shoot browning in SW Spain using online imagery as virtual prospecting tool. Ann. For. Sci. 2019, 76, 32. [CrossRef]

56. Aćimović, S.G.; Harmon, C.L.; Bec, S.; Wyka, S.; Broders, K.; Doccola, J.J. First report of Diplodia corticola causing decline of red oak (Quercus rubra) trees in Maine. Plant Dis. 2016, 100, 649. [CrossRef]

57. Barradas, C.; Phillips, A.J.L.; Correia, A.; Diogo, E.; Bragança, H.; Alves, A. Diversity and potential impact of Botryosphaeriaceae species associated with Eucalyptus globulus plantations in Portugal. Eur. J. Plant Pathol. 2016, 146, 245-257. [CrossRef]

58. Smahi, H.; Belhoucine-Guezouli, L.; Bouhraoua, R.T.; Franceschini, A.; Linaldeddu, B.T. First report of branch canker and dieback caused by Cryphonectria naterciae on Quercus suber in Algeria. Plant Dis. 2018, 102, 251. [CrossRef]

59. Luque, J.; Pera, J.; Parladé, J. Evaluation of fungicides for the control of Botryosphaeria corticola on cork oak in Catalonia (NE Spain). For. Pathol. 2008, 38, 147-155. [CrossRef] 
60. Serrano, M.S.; Romero, M.A.; Jimenez, J.J.; De Vita, P.; Avila, A.; Trapero, A.; Sanchez, M.E. Preventive control of Botryosphaeria canker affecting Quercus suber in southern Spain. Forestry 2015, 88, 500-507. [CrossRef]

61. Cimmino, A.; Maddau, L.; Masi, M.; Evidente, M.; Linaldeddu, B.T.; Evidente, A. Further secondary metabolites produced by Diplodia corticola, a fungal pathogen involved in cork oak decline. Tetrahedron 2016, 72, 6788-6793. [CrossRef]

62. Inácio, M.L.; Henriques, J.; Sousa, E. Contribution of Symbiotic Fungi to Cork Oak Colonization by Platypus cylindrus (Coleoptera: Platypodidae). Silva Lusit. 2011, 19, 89-99.

63. Kostovcik, M.; Bateman, C.C.; Kolařík, M.; Stelinski, L.L.; Jordal, B.H.; Hulcr, J. The ambrosia symbiosis is specific in some species and promiscuous in others: Evidence from community pyrosequencing. ISME J. 2015, 9, 126-138. [CrossRef] [PubMed]

64. Dissanayake, A.J.; Camporesi, E.; Hyde, K.D.; Phillips, A.J.L.; Fu, C.Y.; Yan, J.Y.; Li, X.H. Dothiorella species associated with woody hosts in Italy. Mycosphere 2016, 7, 51-63. [CrossRef]

65. Lynch, S.C.; Eskalen, A.; Zambino, P.J.; Mayorquin, J.S.; Wang, D.H. Identification and pathogenicity of Botryosphaeriaceae species associated with coast live oak (Quercus agrifolia) decline in southern California. Mycologia 2013, 105, 125-140. [CrossRef] [PubMed]

66. Smahi, H.; Belhoucine-Guezouli, L.; Berraf-Tebbal, A.; Chouih, S.; Arkam, M.; Franceschini, A.; Linaldeddu, B.T.; Phillips, A.J.L. Molecular characterization and pathogenicity of Diplodia corticola and other Botryosphaeriaceae species associated with canker and dieback of Quercus suber in Algeria. Mycosphere 2017, 8, 1261-1272, doi 105943/mycosphere/8/2/10. [CrossRef]

67. Linaldeddu, B.T.; Sirca, C.; Spano, D.; Franceschini, A. Variation of endophytic cork oak-associated fungal communities in relation to plant health and water stress. For. Pathol. 2011, 41, 193-201. [CrossRef]

68. Lynch, S.C.; Zambino, P.J.; Scott, T.A.; Eskalen, A. Occurrence, incidence and associations among fungal pathogens and Agrilus auroguttatus, and their roles in Quercus agrifolia decline in California. For. Pathol. 2014, 44, 62-74. [CrossRef]

69. Campos, P.; Daly-Hassen, H.; Ovando-Pol, P. Cork oak forest management in Spain and Tunisia: Two case studies of conflicts between sustainability and private income. Int. For. Rev. 2007, 9, 610-626. [CrossRef]

70. Costa, A.; Pereira, H.; Madeira, M. Analysis of spatial patterns of oak decline in cork oak woodlands in Mediterranean conditions. Ann. For. Sci. 2010, 67, 204. [CrossRef] 